\title{
Optimization of Double Transesterification for Biolubricant Synthesis from Jatropha Oil
}

\author{
Muhammad Sani Shehu ${ }^{1}$, Sani Inuwa Lamido ${ }^{2}$, Aminu Uba Alhassan ${ }^{3}$ \\ Department of Chemical Engineering, Kaduna Polytechnic, Kaduna, Nigeria ${ }^{1,2,3}$
}

\begin{abstract}
Bio-lubricant was produced via double transesterification process of Jatropha oil with Ethylene Glycol as a polyol in the presence of potassium hydroxide catalyst. Response Surface Methodology (RSM) using Central Composite Design (CCD) was performed by Design expert v10 software to determine the optimum operating conditions for bio-lubricant Lubricity. In this study, the process variables optimized were temperature, catalyst concentration and reaction time. From the Analysis Of Variance (ANOVA), the most influential parameter on biolubricant production was catalyst concentration. The predicted lubricity was found in good agreement with the experimental value, with coefficient of determination $\left(\mathrm{R}^{2}\right)=0.9785$. The optimum bio-lubricant lubricity of 517.030 was achieved at $2.62 \mathrm{hr}$ reaction time, with $0.95 \mathrm{wt} \%$ of catalyst concentration and with temperature of $149.73^{\circ} \mathrm{C}$. Major lubricating properties of the product such as: density at $100{ }^{\circ} \mathrm{C}$, kinematic viscosity at $40{ }^{\circ} \mathrm{C}$, viscosity at $40^{\circ} \mathrm{C}$, viscosity index, and the pour point were found to be: $0.922 \mathrm{mg} / 1,5.58 \mathrm{~mm}^{2} / \mathrm{s}, 35.8 \mathrm{~N} . \mathrm{s} / \mathrm{m}^{2}, 169$ and $-7{ }^{\circ} \mathrm{C}$ respectively. The bio-lubricant produced is comparable to the standards commercial lubricants ISO VG-46 for light and industrial gears applications.
\end{abstract}

Keywords: Bio-lubricant, Jatropha, Double Transesterification, Response Surface Methodology (RSM) and Central Composite Design (CCD)

\section{INTRODUCTION}

Lubricants derived from petroleum base are the most widely used in almost all applications despite their adverse environmental effects caused by their toxicity and non-biodegradability [1,2]. Biolubricants (bio base oil + additives) are vital substitutes to petro-base lubricants because of their numerous advantages such as they are renewable, environmentally friendly, biodegradable, less toxicity [3]. Biodegradable lubricants gotten from bio- base subtances therefore becomes a new and very important area of research based on the increasing concern for environmental security and in addition to the regular increase in the price of petroleum oil [4]. Triglycerides which form the main constituent of vegetable oils comprises of three hydroxyl groups and long chain unsaturated free fatty acids attached at the hydroxyl group by ester linkages [5, 6]. The unsaturated free fatty acids are basically of the type oleic, linoleic, and linolenic which is an indication of the ratio and position of carbon-carbon double bond, one, two and three double bonds of carbon chain respectively [7]. Even though vegetable oils hold numerous qualities, their acceptability and utilization as lubricant base oils is still not widely implemented. The main limitations of vegetable oil are its poor low temperature behavior, oxidation and thermal stability and gumming effect $[8,9,10]$. These undesirable properties of vegetable oils can be enhanced through chemical modifications. The modification on the carboxyl group is performed by two stage of Transesterification process. The first stage involves the conversion of crude vegetable oil into biodiesel i.e. methylester using methanol with base catalyst $\mathrm{KOH}$ and second stage involves the conversion of produced bio-diesel into bio-lubricant using trimethylolpropane with sodium methoxide as catalyst [11,12]. Typical homogeneous catalysts that find usage in biolubricant production are p-toluene sulphonic acid, phosphoric acid, sulphuric acid, sodium hydroxide, sodium ethoxide and sodium methoxide. In some cases, heterogeneous catalysts such as Sn-oxalate or cation exchange resins are used $[13,14]$.

One of the most important stages in the development of an efficient and economic production of high value products is the optimization of parameters. Response surface methodology (RSM) is a statistical tool for optimization in which several factors and their interactive effect can be analysed in a few experimental runs [15]. RSM has been widely applied in several areas some of which include processing of food prroducts, development and improvement of new products, biotechnology and bioprocessing such as in fermentation studies and enzymatic hydrolysis [15]. RSM is a collection of mathematical and statistical techniques for designing experiments, building models, evaluating the effects of factors, and searching optimum condition of factors for desired responses. The optimization process of this methodology involves studying the response of statistically designed combinations, estimating the coefficients by fitting it in mathematical model that fits best the experimental conditions, predicting the response of the fitted model, and checking the adequacy 


\section{International Advanced Research Journal in Science, Engineering and Technology}

Vol. 6, Issue 5, May 2019

of the model. Central composite design (CCD) and Box-Behnken design (BBD) are amongst the most commonly used in various experiments due to their less experimental runs $[16,17]$.

Emphasis on the development of renewable, biodegradable, and environmentally friendly lubricants has resulted in the widespread use of natural oils and fats. Vegetable oils, such as jatropha seed oils, are promising candidates as base fluid for eco-friendly lubricants because of their excellent lubricity, biodegradability, viscosity-temperature characteristics and low volatility [18]. In our present study, DESIGN EXPERT V10.1 software is employed to carry out multiple regression and analysis of variance (ANOVA) for the optimization of double transesterification process, as well determining the relative significance of the factors considered for the process.

\section{METHODOLOGY}

\section{Oil Esterification}

This is informed by the need to reduce the free fatty acid (FFA) content of the oil (jatropha seed oil) as it may lead to high saponification. The high FFA content of the oil was reduced by the esterification of the oils with methanol using sulphuric acid as catalyst.500g of the oil samples was weighed and transferred into a three necks round bottom flask. 20 $\% \mathrm{w} / \mathrm{w}$ methanol and $5 \% \mathrm{w} / \mathrm{w}$ sulphuric acid were also weighed and mixed in a conical flask. The methanol-acid mixture and the oil sample were placed in a water bath and heated to a temperature of $60{ }^{\circ} \mathrm{C}$. Mechanical stirrer was inserted through one of the necks while the other two necks were Stoppard by the stirrer rotating at $700 \mathrm{rpm}$. The temperature of the bath was maintained at $60{ }^{\circ} \mathrm{C}$ for homogeneity. At this moment, timing started. After 60 min, pipette was used to withdraw the sample and was titrated against $0.1 \mathrm{~N}$ solution of $\mathrm{KOH}$ to determine the free fatty acid content of the oil. The titration was repeated for 60 min intervals up to the 240 min the free fatty acid value was calculated according to Equation 1:

\section{Transesterification}

$$
\% \mathrm{FFA}=\frac{(\mathrm{mL} \text { of titrant })(\text { Normality of titrant }) * 56-1}{\text { Sample weigth }}
$$

Production (synthesis) of biolubricant involves a two stage transesterification process; the first one is aimed at producing an intermediate product- methyl ester of the oils, while the second uses the methyl ester as reactant to produce the desired product- a polyol ester. The two processes proceed as follows:

\section{Methyl Ester Synthesis}

$400 \mathrm{~g}$ of the oil was transesterified with methanol using sodium hydroxide as catalyst. The weight ratio of oil-tomethanol was $3: 1$; the amount of catalyst used was $0.5 \% \mathrm{w} / \mathrm{w}$ of the oil. The reaction was conducted at a temperature of $60{ }^{\circ} \mathrm{C}$ for one hour to produce biodiesel and glycerin. The biodiesel was separated by gravity from the glycerin using separating funnel after leaving it to settle for $20 \mathrm{~h}$

\section{Polyolester (Biolubricant) Synthesis}

This was achieved by transesterification of the methyl ester with ethylene glycol using potassium hydroxide as catalyst. The weight ratio of vegetable oil methyl ester-to-ethylene glycol was 4:1, potassium hydroxide catalyst was measured base on the percentage of each experimental run into the reactor, temperature of the reaction was raised to that of each experimental run and the reaction time was maintained base on each experimental run [19]. Constant vacuum condition was applied at each experimental run in other to reduce excessive foam formation as a result of methanol loss.

\section{Experimental Design and Optimization}

A five-level, three-factorial central composite design (CCD) was applied yielding a 8 factorial experiments, 6 axial points and 6 center points, $\mathrm{k}$ represent the number of independent variables which are temperature, time and catalyst concentration. $\pm \alpha=2 \mathrm{n} / 3$ gives the distance from the axial point from the center point, $\mathrm{n}$ is the number of factors $(\alpha=$ 1.62). The temperature was varied between $120{ }^{\circ} \mathrm{C}$ and $150{ }^{\circ} \mathrm{C}$, reaction time between 1 and 3 hours and catalyst loading between 0.8 and $1 \% \mathrm{w} / \mathrm{w}$, these were based on literatures. Table 1 present Codes, ranges and levels of independent variables of temperature $(\mathrm{T})$, time $(\mathrm{t})$ and catalyst concentration $(\mathrm{C})$ in RSM design while the catalyst percentage, the reaction temperature and the reaction time for each experimental run are shown in Table 1.

Table 1: Coded and Uncoded Levels of the Independent Variables.

\begin{tabular}{lllllll}
\hline Symbols & $\begin{array}{l}\text { Independent } \\
\text { Variables }\end{array}$ & -1.68 & -1 & Coded & Levels & \\
& T $\left({ }^{\circ} \mathrm{C}\right)$ & 109.8 & 120 & 135 & 150 & 1.68 \\
\hline X1 & t $($ hr $)$ & 0.32 & 1 & 2 & 3 & $\mathbf{1 6 0 . 2}$ \\
X2 & C $(\%$ w/w $)$ & 0.732 & 0.8 & 0.9 & 1 & 1.068 \\
X3 & & &
\end{tabular}




\section{International Advanced Research Journal in Science, Engineering and Technology}

Vol. 6, Issue 5, May 2019

The results for the lubricity for each experimental run of the input parameters (i.e., temperature, time and concentration) are shown in Table 2. Also, the difference between the experimental and predicted values which is the residual which shows a minute difference for the response parameter at the design points and all the three variables in the uncoded form are given in the same Table 2.

\section{Polynomial Modelling}

The lubricity equation in term of uncoded factor is given in equation 2:

$$
\begin{aligned}
Y= & -2814.61467+9.04262 A+240.51722 B+4700.60626 C- \\
& 0.30000 A B-2.83333 A C-45.00000 B C-0.012573 A^{2}- \\
& 28.10791 B^{2}-2227.42777 C^{2}
\end{aligned}
$$

Eliminating the non-significant effects, equation 2 reduces to:

$$
\mathrm{Y}=\underset{\mathbf{2 2 2 7 . 4 3} C^{\mathbf{2}}}{\mathbf{2} 814.62+9.04 A}+\mathbf{2 4 0 . 5 2 B}+\mathbf{4 7 0 0 . 6 1 C - 2 8 . 1 1 B ^ { 2 } -}
$$

The value of coefficient of determination $\left(\mathrm{R}^{2}\right)$ for the model was 0.9129 and Adjusted $\mathrm{R}^{2}$ is 0.9785 both indicating the good fitness of the model. The p-value of the parameters where also investigated, reaction time and catalyst concentration all have significant effect on the response parameter (Lubricity) with p-values less than 0.05 ( $\mathrm{P}$-value< 0.05 ) as shown in Table 3. Also, the quadratic terms of the parameter (reaction time and catalyst concentration) all have significant effect on the response parameter with p-values $<0.05$ while the interaction between the temperature and catalyst concentration have significant effect on the response parameter with p-values $<0.05$ but while the linear and quadratic parameters of temperature with the interaction parameter of reaction time with catalyst concentration and temperature with reaction time parameters have no significant effect on the response parameter (Lubricity).

\section{Analysis of Variance (ANOVA)}

Statistical analysis of the design model was performed using Design Expert V10.1 to estimate the ANOVA and check the adequacy of the model. The results of ANOVA for fitting the quadratic response surface model by mean square method and also checking the adequacy of the model are summarized in Table 4. The significance of the model equation was evaluated by the F-value for analysis of variance, 96.95 implies the model is significant. There is only a $0.01 \%$ chance that an F-value this large could occur due to noise. Values of "Prob> F" less than 0.0500 indicate model terms are significant. In this case $\mathrm{A}, \mathrm{B}, \mathrm{C}, \mathrm{B}^{\wedge} 2, \mathrm{C}^{\wedge} 2$ are significant model terms. Values greater than 0.1000 indicate the model terms are not significant. If there are many insignificant model terms (not counting those required to support hierarchy), however model reduction may be applied to improve the model. The value of coefficient of determination $\left(\mathrm{R}^{2}\right)$ for the model was 0.9887 and Adjusted $\mathrm{R}^{2}$ is 0.9785 both indicating the good fitness of the model.

Table 2: Design Matrix of Experiment and Their Respective Experimental, Predicted and Residual Lubricity

\begin{tabular}{lllllll}
\hline $\begin{array}{l}\text { Run } \\
\text { Order }\end{array}$ & $\begin{array}{l}\text { Tempt. } \\
\left({ }^{\circ} \mathrm{C}\right)\end{array}$ & $\begin{array}{l}\text { Time } \\
(\mathrm{hr})\end{array}$ & $\begin{array}{l}\text { Catalyst } \\
\text { Conc. }\end{array}$ & $\begin{array}{l}\text { Experimental } \\
\text { Lubricity(N/s) }\end{array}$ & $\begin{array}{l}\text { Predicted } \\
\text { Lubricity(N/s) }\end{array}$ & Residual \\
\hline 1 & 120 & 3 & 1 & 440 & 448.21 & -8.21 \\
2 & 135 & 2 & 0.9 & 465 & 465.68 & -0.68 \\
3 & 150 & 1 & 1 & 435 & 429.48 & 5.52 \\
4 & 135 & 2 & 0.9 & 466 & 465.68 & 0.32 \\
5 & 135 & 2 & 1.07 & 449 & 439.47 & 9.53 \\
6 & 135 & 0.32 & 0.9 & 297 & 307.00 & -10.00 \\
7 & 109.77 & 2 & 0.9 & 401 & 394.67 & 6.33 \\
8 & 135 & 2 & 0.73 & 357 & 365.90 & -8.90 \\
9 & 150 & 3 & 1 & 497 & 505.65 & -8.65 \\
10 & 120 & 1 & 0.8 & 301 & 292.79 & 8.21 \\
11 & 135 & 2 & 0.9 & 467 & 465.68 & 1.32 \\
12 & 160.23 & 2 & 0.9 & 515 & 520.70 & -5.70 \\
13 & 120 & 1 & 1 & 349 & 354.04 & -5.04 \\
14 & 135 & 2 & 0.9 & 466 & 465.68 & 0.32 \\
15 & 150 & 3 & 0.8 & 484 & 479.41 & 4.59 \\
16 & 135 & 2 & 0.9 & 465 & 465.68 & -0.68 \\
17 & 135 & 3.68 & 0.9 & 476 & 465.37 & 10.63 \\
18 & 120 & 3 & 0.8 & 399 & 404.97 & -5.97 \\
19 & 135 & 2 & 0.9 & 465 & 465.68 & -0.68 \\
20 & 150 & 1 & 0.8 & 393 & 385.23 & 7.77 \\
\hline
\end{tabular}

Table 3: Regression Coefficient of Predicted Quadratic Polynomial Model for Lubricity 
International Advanced Research Journal in Science, Engineering and Technology

Vol. 6, Issue 5, May 2019

\begin{tabular}{lllllllll}
\hline Factor & $\begin{array}{l}\text { Coefficient } \\
\text { Estimate }\end{array}$ & Df & $\begin{array}{l}\text { Standard } \\
\text { Error }\end{array}$ & $\begin{array}{l}-95 \% \text { CI } \\
\text { Low }\end{array}$ & $\begin{array}{l}+95 \% \text { CI } \\
\text { High }\end{array}$ & VIF & p-value & Remark \\
\hline Intercept & -2814.61 & 1 & 400.39 & -3706.75 & -1922.48 & & $<0.0001$ & significant \\
A-Tempt. & 9.04 & 1 & 3.52 & 1.19 & 16.89 & 453.14 & 0.0280 & Significant \\
B-Time & 240.52 & 1 & 42.46 & 145.90 & 335.13 & 292.71 & 0.0002 & Significant \\
C-Conc. & 4700.61 & 1 & 528.34 & 3523.4 & 5877.83 & 453.14 & $<0.0001$ & Significant \\
AB & -0.30 & 1 & 0.22 & -0.78 & 0.18 & 146.10 & 0.1954 & \\
AC & -2.83 & 1 & 2.16 & -7.65 & 1.98 & 277.55 & 0.2193 & \\
BC & -45.00 & 1 & 32.43 & -117.26 & 27.26 & 146.10 & 0.1954 & \\
$A^{2}$ & -0.013 & 1 & 0.011 & -0.036 & 0.011 & 308.06 & 0.2688 & Significant \\
$\mathrm{B}^{2}$ & -28.11 & 1 & 2.42 & -33.49 & -22.72 & 16.18 & $<0.0001$ & Significant \\
$\mathrm{C}^{2}$ & -2227.43 & 1 & 241.61 & -2765.78 & -1689.08 & 308.06 & $<0.0001$ & \\
$\mathrm{R}^{2}=$ & 0.9887 & & & & & & & \\
Adjusted $\mathrm{R}^{2}=$ & 0.9785 & & & & & & & \\
\hline
\end{tabular}

Table 4: ANOVA for Polynomial Quadratic Model

\begin{tabular}{|c|c|c|c|c|c|c|c|c|}
\hline Source & $\begin{array}{l}\text { Sum of } \\
\text { Squares }\end{array}$ & Df & $\begin{array}{l}\text { Mean } \\
\text { Square }\end{array}$ & $\begin{array}{l}-95 \% \text { CI } \\
\text { Low }\end{array}$ & $\begin{array}{l}+95 \% \text { CI } \\
\text { High }\end{array}$ & F-Value & $\begin{array}{l}\text { p-value } \\
\text { Prob> F }\end{array}$ & Remark \\
\hline Model & 73409.26 & 9 & 8156.58 & -3706.75 & -1922.48 & 96.95 & $<0.0001$ & Significant \\
\hline A-Tempt. & 554.48 & 1 & 554.48 & 1.19 & 16.89 & 6.59 & 0.0280 & significant \\
\hline B-Time & 2698.98 & 1 & 2698.98 & 145.90 & 335.13 & 32.08 & 0.0002 & significant \\
\hline C-Conc. & 6659.22 & 1 & 6659.22 & 3523.4 & 5877.83 & 79.15 & $<0.0001$ & Significant \\
\hline $\mathrm{AB}$ & 162.00 & 1 & 162.00 & -0.78 & 0.18 & 1.93 & 0.1954 & \\
\hline $\mathrm{AC}$ & 144.50 & 1 & 144.50 & -7.65 & 1.98 & 1.72 & 0.2193 & \\
\hline $\mathrm{BC}$ & 162.00 & 1 & 162.00 & -117.26 & 27.26 & 1.93 & 0.1954 & \\
\hline$A^{2}$ & 115.32 & 1 & 115.32 & -0.036 & 0.011 & 1.37 & 0.2688 & \\
\hline $\mathrm{B}^{2}$ & 11385.71 & 1 & 11385.71 & -33.49 & -22.72 & 135.34 & $<0.0001$ & Significant \\
\hline $\mathrm{C}^{2}$ & 7150.07 & 1 & 7150.07 & -2765.78 & -1689.08 & 84.99 & $<0.0001$ & Significant \\
\hline Residual & 841.29 & 10 & 84.13 & & & & & \\
\hline Lack of Fit & 837.96 & 5 & 167.59 & & & 251.39 & $<0.0001$ & Significant \\
\hline Pure Error & 3.33 & 5 & 0.67 & -3706.75 & -1922.48 & & & \\
\hline Cor Total & 74250.55 & 19 & & 1.19 & 16.89 & & & \\
\hline
\end{tabular}

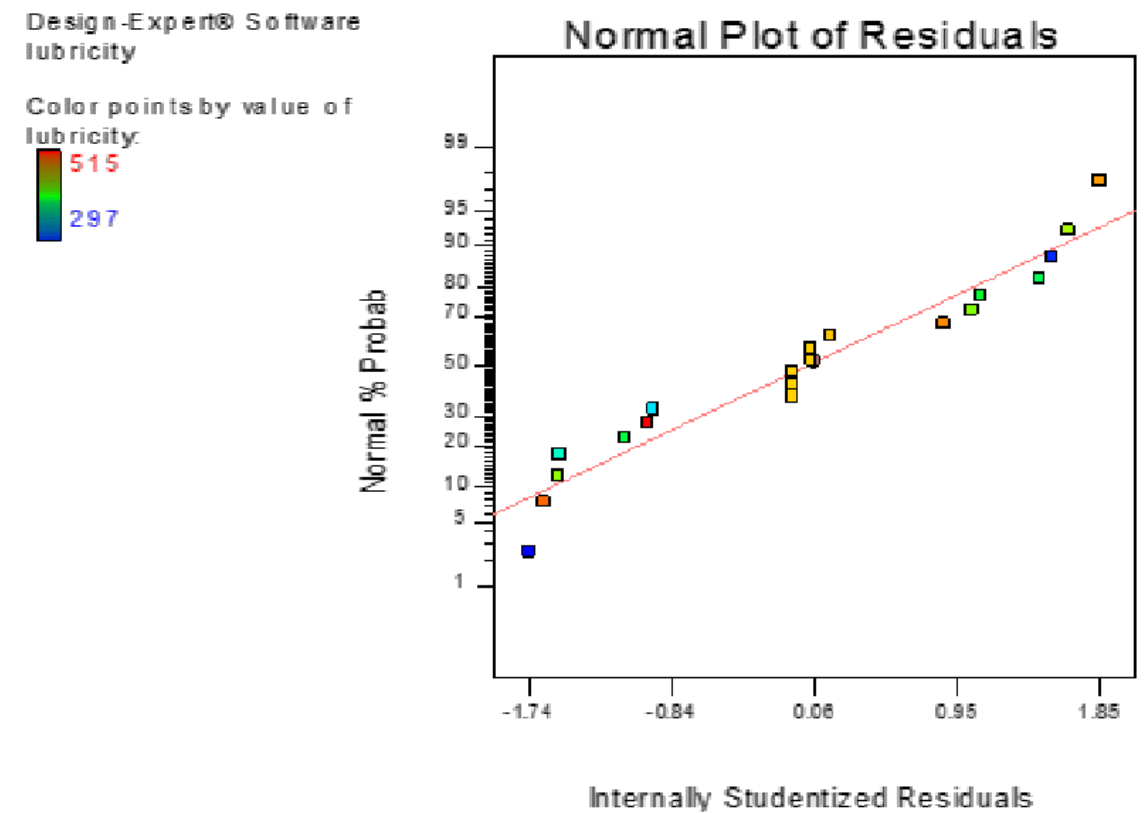

Fig.1: Normal Plot of Residual 


\section{International Advanced Research Journal in Science, Engineering and Technology}

Vol. 6, Issue 5, May 2019
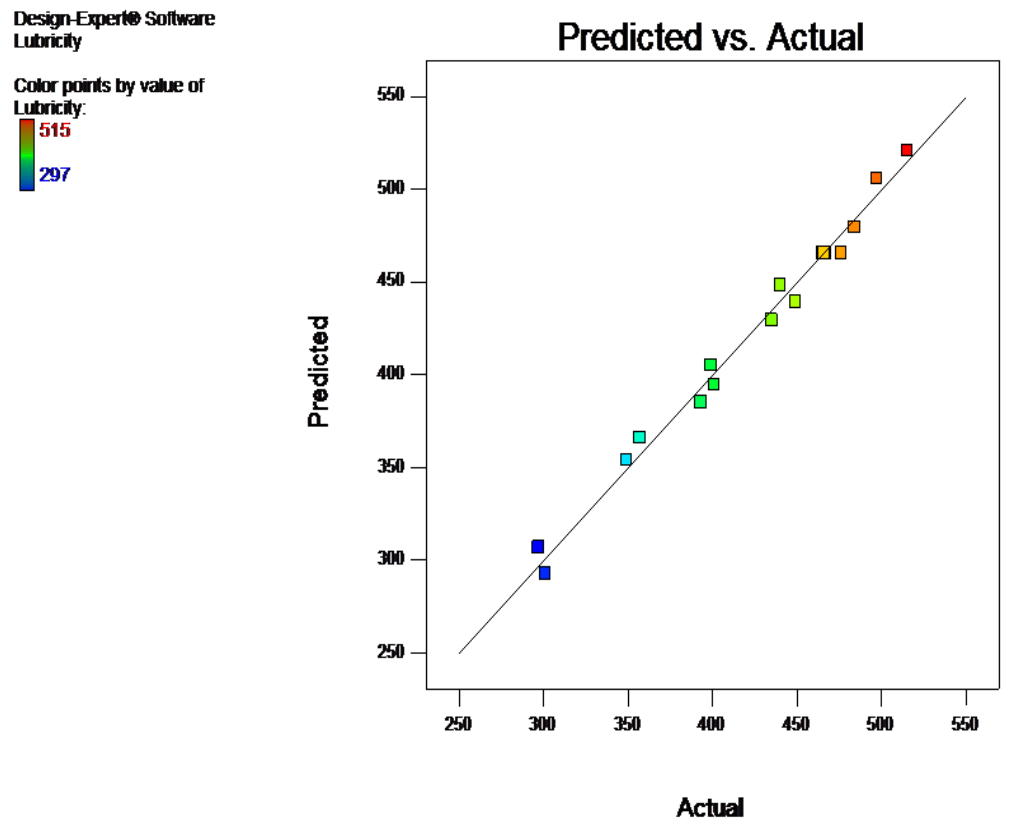

Fig. 2: Actual Vs Predicted Values Plot for Lubricity

Fig 1 shows the normal plot of residuals whereas, that of Predicted Vs Actual Plot for Lubricity response is shown in Fig. 2. This shows the closeness of the experimented actual values denoted by the colored squared boxes to the predicted model values represented by the dark line. Thus, the predicted model with coefficient of determinant $\left(\mathrm{R}^{2}\right)$ of 0.9887 can be used to predict the lubricity response of the experimental actual values

\section{Response Surface Analysis}

The 3D plot shows the effect of interaction among the variables: catalyst concentration and temperature, reaction time and catalyst concentration, and reaction time and temperature on biolubricant lubricity are presented in Fig. 3, 4 and 5 respectively. The effect of catalyst concentration and temperature on biolubricant lubricity is shown in Fig 3 . The optimum lubricity is achieved at high catalyst concentration and temperature with prevalence of quadratic effect for catalyst concentration. Fig. 4 illustrates the effects of time and catalyst concentration on the lubricity, the response plot shows the same pattern just discussed, but with both having a quadratic effect. Fig. 5 indicates the combined effects of temperature and time on the lubricity. This effects is similar to that of Fig. 3 with time having a quadratic. This further explains that all the three plots are devoid of high significance of linear effects of the variables, but with overall quadratic effect being most significant. This gives a curvature of the response surface and the optimum to be located near the topmost position of the surface.

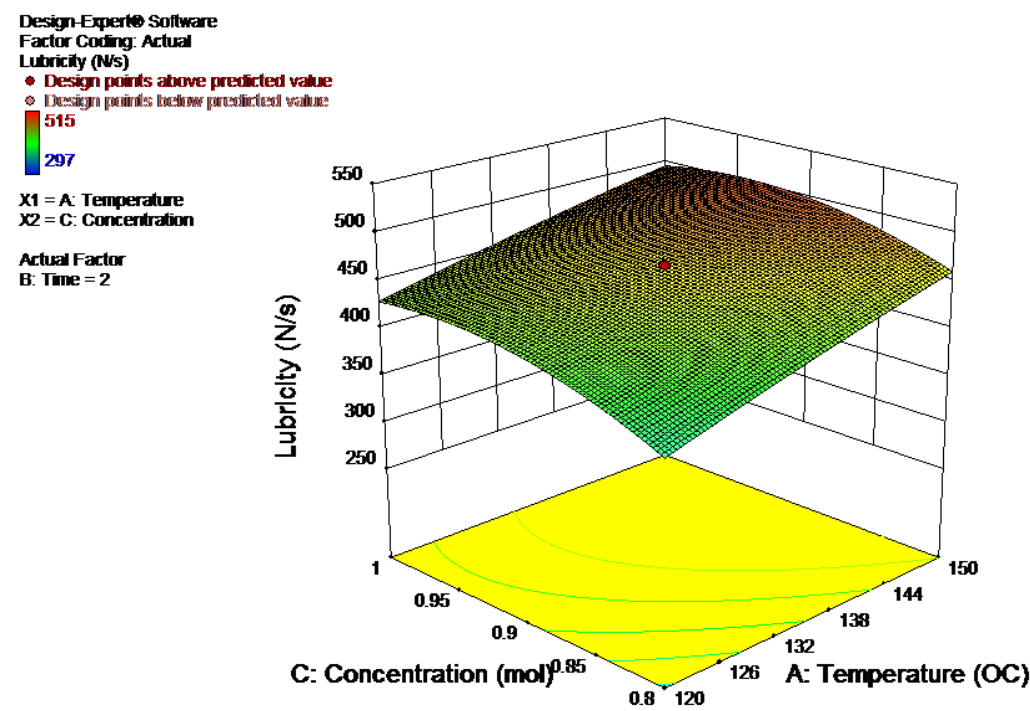

Fig. 1: 3D Response Surface Plot of Lubricity against Temperature and Catalyst concentration 


\section{International Advanced Research Journal in Science, Engineering and Technology}

Vol. 6, Issue 5, May 2019

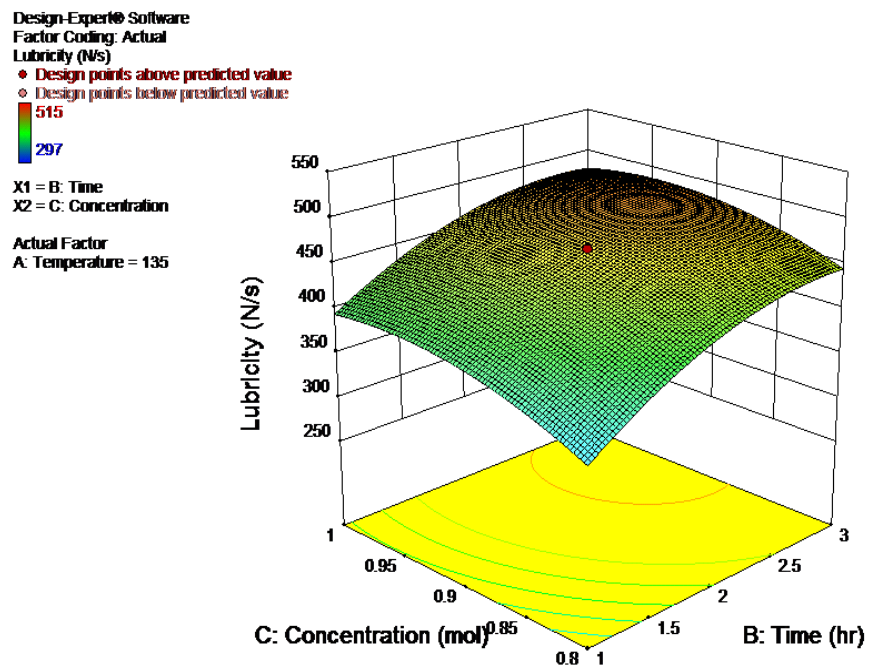

Fig. 2: 3D Response Surface Plot of Lubricity against the Catalyst Concentration and Reaction Time.

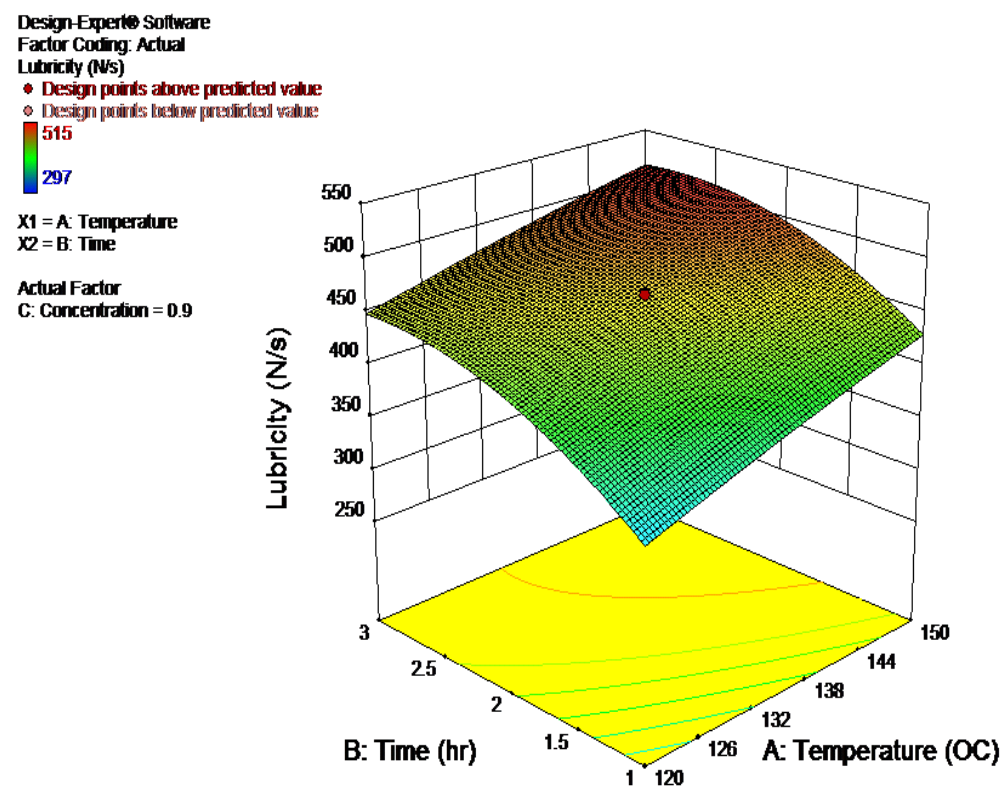

Fig. 3: 3D Response Surface Plot of Lubricity against Reaction Time and Temperature

\section{Optimization and Validation of Lubricity}

Numerical optimization technique based on desirability function was carried out to determine the workable optimum conditions for maximizing the produced biolubricant lubricity. In order to provide an ideal case for biolubricant lubricity, the goal for temperature, reaction time and catalyst concentration was set in range based upon the requirements of the lubricity. The result of the factor settings and optimization, predicted responses at the current level of each factor (uncoded) in the model are presented in Table 5 and Fig. 4 respectively.

\section{Validation Experiment}

In order to verify the optimization results, an experiment was performed under the predicted conditions by the developed model. The model predicted $517.030 \mathrm{~N} / \mathrm{m}$ biolubricant lubricity with experimental desirability of 1.0000 at $149.73{ }^{\circ} \mathrm{C}$ temperature, $2.62 \mathrm{~h}$ reaction time and $0.953 \mathrm{~mol} \%$ catalyst concentration as presented in Table 5 and well presented in Fig. 4. The experimental value obtained at these conditions was $516.71 \mathrm{~N} / \mathrm{m}$ which has deviated from the predicted was not in agreement and hence the need to validate the findings of the optimization. 


\section{International Advanced Research Journal in Science, Engineering and Technology}

Vol. 6, Issue 5, May 2019

Table 5 Desirability

\begin{tabular}{ccccccc}
\hline Number & Temperature & Time & Concentration & Lubricity & Desirability & \\
\hline 1 & 149.027 & 2.642 & 0.906 & 515.040 & 1.000 & \\
2 & 148.771 & 2.787 & 0.933 & 516.434 & 1.000 & \\
3 & 149.758 & 2.791 & 0.963 & 516.098 & 1.000 & \\
4 & 148.775 & 2.719 & 0.914 & 515.663 & 1.000 & \\
5 & 149.431 & 2.516 & 0.953 & 515.604 & 1.000 & \\
6 & 149.701 & 2.510 & 0.912 & 515.643 & 1.000 & \\
7 & 149.659 & 2.515 & 0.959 & 515.426 & 1.000 & \\
8 & $\underline{149.730}$ & $\underline{2.616}$ & $\underline{0.953}$ & $\underline{517.030}$ & $\underline{1.000}$ & Selected \\
9 & 148.801 & 2.821 & 0.912 & 515.480 & 1.000 & \\
10 & 149.194 & 2.454 & 0.940 & 515.019 & 1.000 & \\
\hline
\end{tabular}

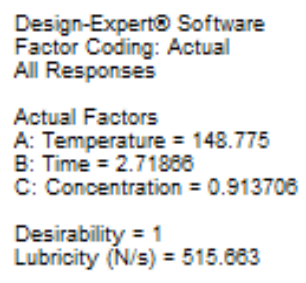

\section{A: Temperature (OC) B: Time (hr) C: Concentration (mol)}

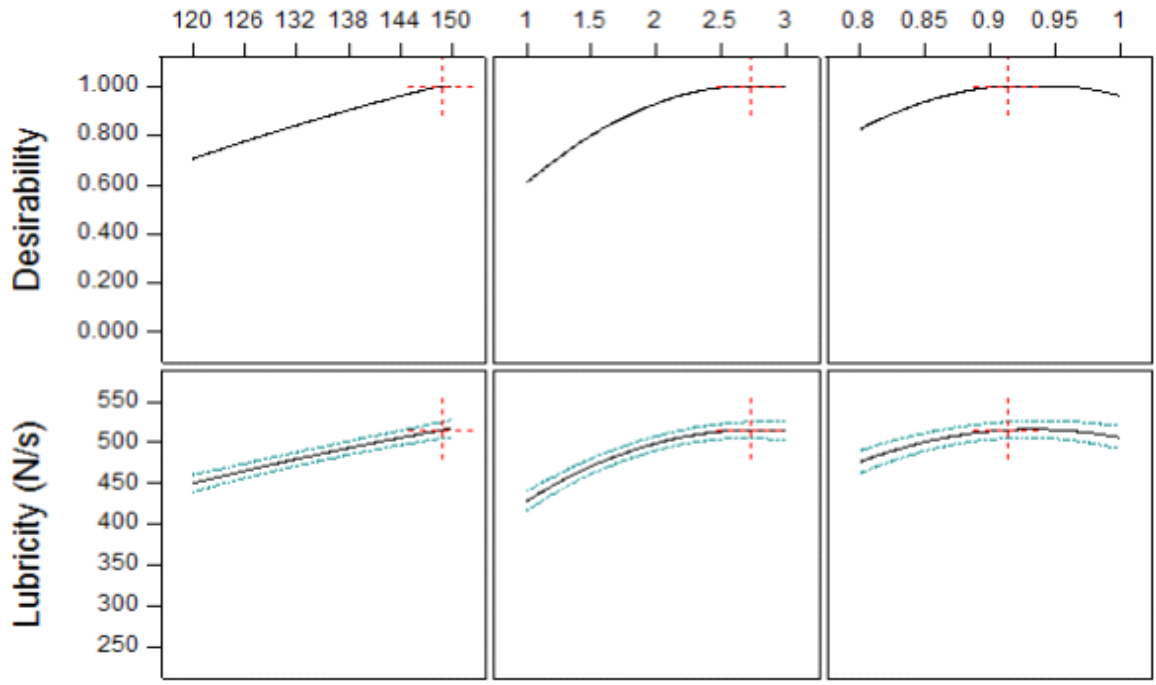

Fig. 4: Response Surface Profile for Lubricity and Desirability

Table 6: Physiochemical Properties of Biolubricant Produced from Jatropha Oil

\begin{tabular}{lll}
\hline Properties & Biolubricant & ISO VG-46 \\
\hline Density at $100^{\circ} \mathrm{C}(\mathrm{mg} / \mathrm{l})$ & 0.922 & 0.860 \\
Kinematic viscosity at $40{ }^{\circ} \mathrm{C}\left(\mathrm{mm}^{2} / \mathrm{s}\right)$ & 5.58 & $4.14-5.60$ \\
Kinematic viscosity at $100^{\circ} \mathrm{C}\left(\mathrm{mm}^{2} / \mathrm{s}\right)$ & 10.310 & $9.3-12.5$ \\
viscosity $\left(\mathrm{N} . \mathrm{s} / \mathrm{m}^{2}\right) 40^{\circ} \mathrm{C}$ & 35.8 & 45 \\
viscosity(N.s/ $\left.{ }^{2}\right) 100^{\circ} \mathrm{C}$ & 9.3 & 6.5 \\
Lubricity $(\mathrm{N} / \mathrm{s})$ & 517.03 & $200-520$ \\
Viscosity Index & 169 & $140-200$ \\
Pour point & 7 & $>10$ \\
Free Fatty Acid $(\%)$ & $0.280 \%$ & $\leq 0.4 \%$ \\
\hline
\end{tabular}

The predicted maximum (uncoded) values of temperature, catalyst concentration and reaction time at the maximum desirability were found to be $\left(149.73{ }^{\circ} \mathrm{C}\right),(0.953 \mathrm{~mol} \%)$ and $2.62 \mathrm{~h}$ respectively, to achieve 517.03 maximum biolubricant lubricity; while desirability was 1.0000 for the experiment [Fig. 4]. 


\section{International Advanced Research Journal in Science, Engineering and Technology}

Vol. 6, Issue 5, May 2019

\section{Confirmatory Test: Physiochemical Property of the Optimum Biolubricant Produced}

The optimum biolubricant produced using the optimum conditions which are $149.730\left({ }^{\circ} \mathrm{C}\right.$ ) temperature, $0.953(\mathrm{wt} \%)$ catalyst concentration and reaction time of 2.616 (hrs) was characterized for suitability and utilization to determine if its lubricity equates the predicted model and test the physiochemical properties of the biolubricant produced based on the ASTM D6751 standards. Table 6 shows that the lubricity obtained from the optimized biolubricant almost equate the predicted model, confirming a good fitness of the model for the experimental runs and most of physiochemical property of the biolubricant produced like viscosity, density, pour point and viscosity index compared favourably with the ISO VG-46 for biolubricant quality.

\section{CONCLUSION}

The optimization of transesterification process of Jatropha curcas biolubricant was made possible by three-factorial central composite design using response surface methodology in 20 experimental runs. A second-order quadratic model capable of predicting the Jatropha curcas biolubricant lubricity based on the process variables was developed. $517.03 \mathrm{~N} / \mathrm{s}$ optimum lubricity was predicted at optimum conditions: temperature of $149.73{ }^{\circ} \mathrm{C}$, reaction time of $2.62 \mathrm{hr}$ and catalyst concentration of $0.95 \% \mathrm{w} / \mathrm{w} \mathrm{KOH}$. Statistical analysis of variance (ANOVA) of results shows that temperature and catalyst concentration has a positive effect on the biolubricant lubricity, reaction time effect is less significant on the biolubricant lubricity; however, catalyst concentration has higher effect than the temperature. The properties of the produced biolubricant compared favourably with that of the ISO VG-46 for biolubricant quality.

\section{REFERENCES}

[1]. Anjana Srivastava1 and Preeti Sahai, Vegetable oils as lube basestocks: A review, African Journal of Biotechnology Vol. 12(9), pp. 880-891, 27 February, 2013. http://www.academicjournals.org/AJB DOI: 10.5897/AJB12.2823

[2]. Salih N, Salimon J, Yousif E., Synthetic biolubricant basestocks based on environmentally friendly raw materials. Journal of King Saud University -Science 2011

[3]. M. Shahabuddin, M. A. Kalam, H. H. Masjuki, M. Mofijur. Tribological characteristics of amine phosphate and octylated/butylated diphenylamine additives infused biolubricant. Energy Education Science and Technology Part A: Energy Science and Research 2012; 30:89102 .

[4]. Whitby, R.D., Bio-Lubricants: Applications and prospects, 15th International Colloquium Tribology, TAE, Stuttgart, 2006

[5]. Fox N, Stachowiak G. (2007) Vegetable oil-based lubricants-a review of oxidation. Tribology international; 40:1035-1046.

[6]. Waleska C, David EW, Kraipat C, Joseph MP. The effect of chemical structure of base fluids on antiwear effectiveness of additives. Tribol. Int.; 2005.38:321-6.

[7]. Wagner, H., Luther, R., Mang, T. Lubricant base fluids based on renewable raw materials. Their catalytic manufacture and modification.Appl. Catal. A: Gen. (2003) 221, 429-442

[8]. Willing, A. Lubricants based on renewable resource- an environmentally compatible alternative to mineral oil products. Chemosphere 43:8998.

[9]. Ponnekanti N, Kaul S. Development of ecofriendly/biodegradable lubricants: An overview. 2012.

[10]. Mofijur M, Masjuki H. H, Kalam M. A. et al.Palm Oil Methyl Ester and Its Emulsions Effect on Lubricant Performance and Engine Components Wear. Energy Procedia, International Journal of Current Engineering and Technology 2013; 14:1748-1753

[11]. Amit Kumar Jain and Amit Suhane, Production of Biolubricant from Castor (Ricinus) Oil, International Journal of Engineering Innovation \& Research, Vol.3, No.1 2013 ISSN: $2277-5668$

[12]. Bilal S,Mohammed-Dabo I. A, Nuhu M, Kasim, S. A, Almustapha I. H and Yamusa Y. A. Production of biolubricant from Jatropha curcas seed oil, Journal of Chemical Engineering and Materials Science, Vol. 4(6), pp. 72-79, 2013 DOI 10.5897/JCEMS2013.0164 ISSN 2141-6605.

[13]. Adhvaryu A, Erhan LSZ, Hwang H (2003). Preparation and properties of lubricant basestocks from epoxidised soybean oil and 2-ethylhexanol. JAOCS 80(8):811-815.

[14]. Arumugam S, Sriram G, Subhadra L (2012). Synthesis, chemical modification and tribological evaluation of plant oil as bio-degradable low temperature lubricant. Procedia Eng. 38:1508-1517.

[15]. Lucia Cassettari, Roberto Mosca, Roberto Revetria, Fabio Rolando, Effectiveness and Limits of Response Surface Methodology in Application to Discrete and Stochastic Simulation of Manufacturing Plants, Applied Mathematical Sciences, Vol. 7, 2013 , no. 83, 4137 - 4172. http://dx.doi.org/10.12988/ams.2013.21263.

[16]. G. E. P. Box, W. G. Hunter, and J. S. Hunter, 1978. Statistic for Experimenters, John Wiley \& Sons, New York, NY, USA.

[17]. C.-H. Dong, X.-Q. Xie, X.-L. Wang, Y. Zhan, and Y.-J. Yao, 2009 ."Application of Box-Behnken design in optimisation for polysaccharides extraction from cultured mycelium of Cordyceps sinensis,"Food and Bioproducts Processing,vol.87,no.2,pp.139-144

[18]. Adhvaryu A, Erhan LSZ (2002). Epoxidized soybean oil as potential source of high temperature lubricants. Ind. Crops Prod.15(3):247-254.

[19]. Ghazi, T. I. M., Gunam R. M. F., and Idris A (2010) Production of an improved bio based lubricant from Jatrophacurcas as renewable source. In: Proceedings of the Third International symposium on Energy from Biomass and waste, Nov. 8-11, Venice, Italy, 1-10 